\title{
Humidity and comparative analysis of durability index in pellet of balanced foods for birds
}

\section{Análisis de humedad y comparativo de índice de durabilidad en pellet de los alimentos balanceados para aves}

\author{
VALLEJO-SARTORIUS, Irma †*, RENDON-SANDOVAL, Leticia and GUTIERREZ-PEÑA, Esteban \\ Instituto Tecnológico Superior de Huatusco, Av. 25 Poniente No. 100 Col. Reserva Territorial, Huatusco, Veracruz, México
}

ID $1^{\text {st }}$ Author: Irma, Vallejo-Sartorius / ORC ID 0000-0003-0364-9692, CVU CONACYT ID: 998565

ID $1^{\text {st }}$ Coauthor: Leticia, Rendon-Sandoval / ORC ID 0000-0002-1316-5491, CVU CONACYT ID: 998588

ID $2^{\text {nd }}$ Coauthor: Esteban, Gutierrez-Peña / ORC ID 0000-0003-1160-0223, CVU CONACYT ID: 932865

DOI: $10.35429 / J M Q M .2019 .5 .3 .18 .23$

Received July 28, 2019; Accepted November 10, 2019

\begin{abstract}
The research was carried out to improve the humidity parameters and durability index in the balanced feed for poultry in flour and pellet, to guarantee the quality and avoid contamination in the mycotoxin finished product. Samples of flours and pellets were used for four months to evaluate and standardize the pelletization process, to produce balanced food, which is intended for bird consumption in each of the breeding, posture and fattening phases, guaranteeing them a healthy development. In this investigation, we worked with two pelletizing machines of model 700 and model 702 to keep a statistical control of humidity and durability index (IDP), to avoid product losses in the pelletizing process. The contribution of the present investigation was to reduce the economic impact of the feed processing plant since reprocesses were significantly reduced.
\end{abstract}

Quality, Humidity, Durability

\begin{abstract}
Resumen
La investigación se realizó para mejorar los parámetros de humedad e índice de durabilidad en los alimentos balanceados para aves en harina y pellet, para garantizar la calidad y evitar la contaminación en el producto terminado por micotoxinas. Durante cuatro meses se utilizaron muestras de harinas y pellet con el objetivo de evaluar y estandarizar el proceso de peletizacion, para producir alimento balanceado, el cual está destinado para consumo de aves en cada una de las fases de crianza, postura y engorda, garantizándoles un sano desarrollo. En esta investigación se trabajó con dos máquinas peletizadoras de modelo 700 y modelo 702 para llevar un control estadístico de humedad e índice de durabilidad (IDP), para evitar pérdidas de producto en el proceso de peletizado. La contribución de la presente investigación fue reducir el impacto económico de la planta procesadora de alimentos balanceados, ya que se disminuyeron significativamente los reprocesos.
\end{abstract}

Calidad, Humedad, Durabilidad

Citation: VALLEJO-SARTORIUS, Irma, RENDON-SANDOVAL, Leticia and GUTIERREZ-PEÑA, Esteban. Humidity and comparative analysis of durability index in pellet of balanced foods for birds. Journal-Mathematical and Quantitative Methods. 2019. 3-5: 18-23

\footnotetext{
* Correspondence to Author (email: irvallesar25@hotmail.com)

$\uparrow$ Researcher contributing first author
} 


\section{Introduction}

Pelletization consists of the agglomeration of small particles of a mixture into long units or dense tablets employing a mechanical process combined with moisture, heat, and pressure, all of which determines an improvement of the characteristics in livestock feeds (Benhnke $\mathrm{K}$, 2001). Nutritionally, pelletization allows a natural increase of liquid energy in diets, due to the gelatinization of carbohydrates, reducing energy expenditure in the apprehension of food (McKinney and Teeter, 2004).

The production of quality balanced foods begins with the selection of quality ingredients. The two most common forms of balanced poultry feeds are pellets and flour.

The pelleting process increases the cost of processing, but this cost is recovered by improving some aspects of the feed, the feed conversion improves by $6 \%$ to $7 \%$ compared to flour.

\section{Justification}

To guarantee the quality and safety of the balanced food, controlling the humidity of the flours and the finished product to control the durability index of the pellet using a statistical control of humidity and durability index to standardize the processes and avoid economic losses.

The analysis and control of humidity in model 700 and model 702 machines will allow obtaining better pellet formation that will contribute to a better quality of the finished product as well as in the nutritional quality when conglomerating all the nutrients that the birds must consume.

\section{Problem}

The loss of moisture in some part of the process makes the formation of pellets is not carried out, this being a relevant factor that generates an economic impact of the food processing plant because when obtaining reprocessing money is lost, as well as ensuring the quality and safety of products produced for customer satisfaction.

\section{Hypothesis}

The exact determination of moisture and the product shelf life index (PDI) in poultry feeds is favorable for obtaining a contamination-free feed of acceptable quality.

\section{Objectives}

\section{Overall objective}

Moisture determination and durability index in poultry feeds, guaranteeing better quality, avoiding contamination in the finished product of the feed processing plant.

\section{Specific Objectives}

\section{- Determine moisture control by standardizing the raw material process. Monitor the humidity percentage with the thermobalance for the mixing process of the flours and the finished product. \\ - Temperature verification for humidity control \\ - $\quad$ Record and graph the data obtained for the control of humidity and the Durability Index in products. (PDI)}

\section{Theoretical framework}

\section{The pellet in the poultry industry}

Physiologically, the process of apprehending the bird's food is given by two elements: its vision as the best within the group of vertebrates; and its beak as a keratinized structure, irrigated and innervated by a nervous membrane coming from the trigeminal nerve; this membrane has the socalled "mechanoreceptors," which give the bird the capacity to select certain food particles by means of constant pecking of the food (López C. 2005).

The pelletization process results in faster growth and generally a lower feed conversion rate. The reason for this improved performance is the energy released by the pressing of the mixture. Birds and generally other (production) animal species fed pelleted feed eat about the same number of meals per day as those fed meal but spend less time consuming the pellets (Jansen, 2001 cited by Minoru Miyasaka, 2004). 
The transit of the feed through the gastrointestinal tract is regulated primarily by the crop, where the granulometry plays an important role: fine feeds determine a longer filling time and shorter retention time due to the ease of lubrication and homogenization of the chyme within the crop. Therefore the transit at the intestinal level will be faster, and the absorption process will not be the best; but in granulated feeds, the crop filling time will be shorter, the retention time longer, and the transit of the feed more efficient in terms of absorption and enzymatic activity.

The pellet compared to flour improves the performance of broilers, because more than favoring the development of the gastrointestinal tract, increases the digestibility of nutrients, reducing the viscosity of intestinal content and positively modifies the microfiber. The increase in the digestibility of carbohydrates is due to the breakdown and cooking of granules containing amylase and amylopectin, which facilitates enzymatic action at the digestive level with more contact time and better production. The pelletization when solubilizing partially to the proteins by the alteration of its natural structures releases several nutrients with the rupture of the cellular walls (López C.C.,1999)

\section{Durability}

Durability is the number of fines produced from a sample of pellets after they have been subjected to mechanical or pneumatic agitation. (Thomas \& Van der Poel 1996)

The term durability is defined as a pattern or parameter of physical analysis and is based on the number of pellets or crumblers recovered after being subjected to mechanical or pneumatic agitation, which simulates the transport and handling of pelleted feed under normal conditions within the plant. This parameter is expressed as a percentage.

An IDP with a percentage of $(92-95 \%)$ qualifies a high-quality, durable feed.

(Aarseth et al. 2006b) studied the effect of extrusion temperature on pellet tensile strength. The extrusion temperatures used in their study were $100^{\circ} \mathrm{C}$ and $140^{\circ} \mathrm{C}$. They observed that pellets extruded at higher temperatures showed lower strength, although they were more homogeneous.
Pellet formation occurs at the point where the rollers and the die or output die come into contact. All other activities, such as conditioning, cooling, etc., support the point of contact (Behnke, 2010).

The final moisture content depends on the initial moisture content of the raw materials, although during the production process, we can lose or gain moisture in each of the different production phases. (Stevens 1987) found that as the conditioning temperature increases, the degree of gelatinization of starches decreases. Poultry feeds are conditioned in a temperature range between 80 to $85^{\circ} \mathrm{C}$, and a steam pressure of $138 \mathrm{Kpa}$ and $552 \mathrm{Kpa}$, with a conditioning time between 30 and 60 seconds.

\section{Methodology}

The present investigation was carried out in a poultry feed processing plant, over a period of six months. It consists of three research stages:

Stage 1 Data collection and analysis: During data collection, the process was analyzed in both morning and afternoon shifts at the poultry processing plant, in order to identify flaws in the pellet moisture and durability index parameters. Moisture analyses of raw materials and finished products were performed in the plant's physical analysis laboratory area on a daily basis for four consecutive months to perform statistical analysis.

Stage 2 Process Standardization: A process flow diagram was made Moisture analysis, which consists of the following steps:

- Raw material reception

- Analysis of temperature, humidity, weight/volume of the raw material

- $\quad$ Mixing of raw materials

- The flours go through a thermoconditioner, where they are mixed with $80 \%$ steam

- $\quad$ Peel the flours on a die.

- $\quad$ The product goes through a cooler for 10 minutes.

- $\quad$ It goes through a grinder, depending on the presentation of the food.

- It arrives in the sieve, where it is in charge of separating the flours from the thick 


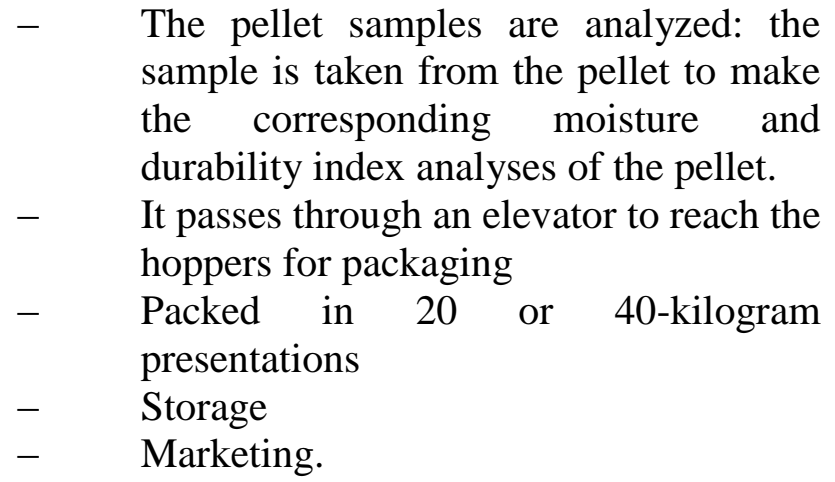

Stage 3:

Processing of the information obtained for statistical analysis in order to determine the PDI, as well as the standardization of humidity for pellet quality control.

\section{Results}

The right moisture level is important because it reduces energy consumption during the compression (pelletizing) process and ensures that production flows smoothly and reduces the risk of blockages. This also serves to reduce damage caused by excessive heat. It also ensures better pellet quality as the optimum level positively affects the hardness of the pellet.

The negative side of increasing the humidity would be to do so with "free" water, which puts the quality of the feed at risk because it would be available for the development of undesirable microorganisms creating rapid growth of fungi with the risk of mycotoxin production.

This typically results in a 0.5 to $1 \%$ loss or depletion in the finished feed compared to the raw materials. Moisture compensation is performed during the mixing process; practical experience shows that adding water alone has a limited potential: after cooling the moisture level in the finished feed is at most equal to the moisture level when it enters the press, even with high additions of water alone, if free water is added the risk of fungal growth is increased, see table 1.

\begin{tabular}{|l|l|l|l|}
\multirow{2}{*}{ Months } & \multicolumn{2}{l}{ Humidity } & \multirow{2}{*}{ Difference } \\
\cline { 2 - 3 } & Flour & Pellet & \\
\hline September & 11.51 & 11.35 & -0.15 \\
\hline October & 11.4 & 11.3 & -0.1 \\
\hline November & 11.72 & 11.54 & -0.18 \\
\hline December & 11.6 & 11.8 & 0.17 \\
\hline
\end{tabular}

Table 1 Final Results of Humidity

Source Own elaboration

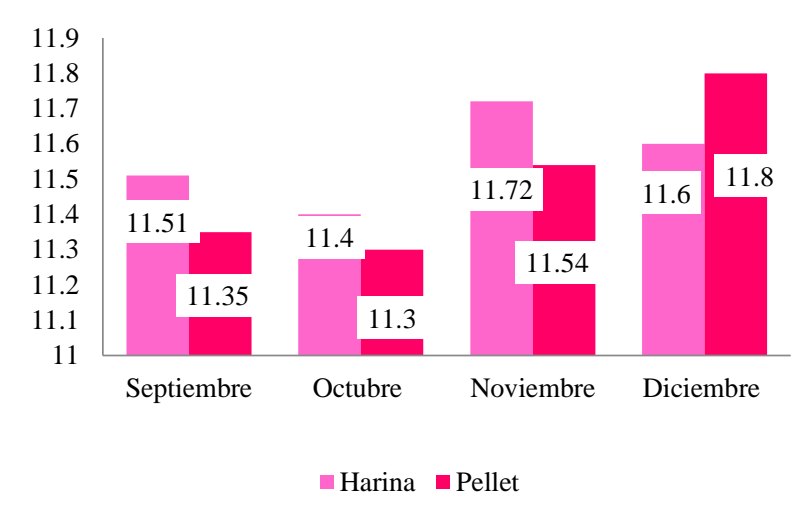

Graph 1 Results of humidity

Source: Prepared by the authors

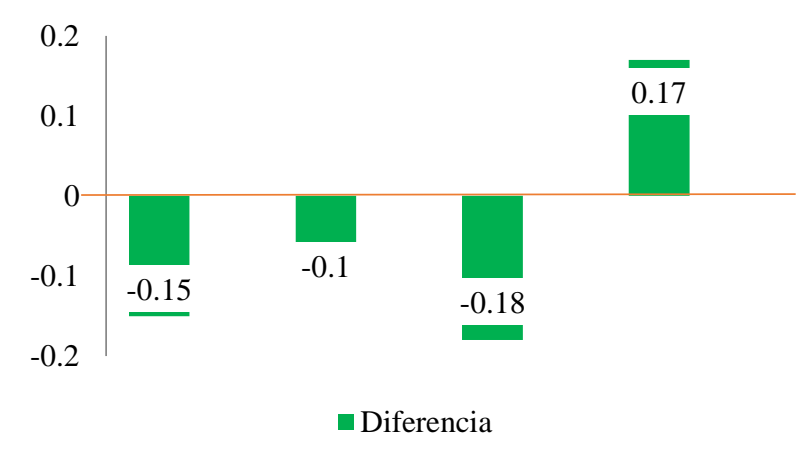

Graph 2 Humidity Difference

Source: Prepared by the authors

Debido a estas pérdidas los productores buscan aprovechar los beneficios de eficiencia y calidad que les da el nivel óptimo de humedad en el alimento terminado.

\section{Durability Index}

Precise measurement of the durability of the pellets allows for an optimal incorporation rate of the binders. Too little pellet binder causes pellet breakage; too much is a waste of money. Lignin, molasses, starch, and steam are the most popular binders.

Today the highest cost is the amount of energy. Granulation is an energy-intensive process. Pelleting presses operate under pressure and are very energy intensive. The goal is to minimize the energy cost and maximize the efficiency of the pelletizing process.

To calculate the Pellet Durability Index, we divide the weight of whole pellets by 500 and multiplying it by 100 . The following Table shows the results of PDI calculation for the two models of machines. 


\begin{tabular}{|l|l|l|l|}
\hline Maq & \multicolumn{1}{|c|}{ Month } & Code & PDI \% \\
\hline $\mathbf{7 0 0}$ & September & $\mathbf{2 9 0}$ & $\mathbf{2 9}$ \\
\hline 700 & October & 290 & 40 \\
\hline $\mathbf{7 0 2}$ & September & $\mathbf{2 9 0}$ & $\mathbf{3 2 . 5}$ \\
\hline 702 & October & 290 & 53 \\
\hline 700 & November & 290 & 40 \\
\hline 702 & November & 290 & 61 \\
\hline 700 & December & 290 & 40 \\
\hline 702 & December & 290 & 67 \\
\hline
\end{tabular}

Table 2 Durability Index Results

The comparison of PDI\% allowed us to determine the hardness of the pellet, indicating the quality of the finished product, concluding that the lower data (29 and 32.5) are the data that gave us the best PDI.

\section{Conclusions}

In this work, we conclude that the obtaining of the humidity of flours as a finished product was registered, and we graphed the results obtained in the drying with the thermobalance. In the graph the results obtained during four months in the first month a flour of 11.51 a finished product of 11 was obtained. 35 and a difference which means that in drying a moisture loss of -0.15 was obtained, in the second month a flour of 11.40 was obtained, a finished product of 11.30 and a difference of -0.1 , in the third month a flour of 11.72 was obtained, a finished product of 11.34 and a difference of -0.18 , in the last month a flour of 11.60 was obtained, a finished product of 11.80 and a difference of 0.17 . We found that the moisture content also varies depending on the product to be pelletized.

The humidity of the finished product cannot exceed an optimum of $12 \%$. Therefore, we conclude that the humidity of such products was kept at the standard so as not to affect the shelf life.

If a product exceeds the optimum humidity, this causes reprocessing and economic and time losses to the company. Thus, this project resulted in more favorable humidity control.

In the verification of temperatures and tons worked per hour of the 700 and 702 pelletizers for their performance. We kept a daily record that allowed a specific control of how much production is worked per shift, as that depends on having a good durability index.

\section{Acknowledgments}

We thank the Instituto Tecnológico Superior de Huatusco.

\section{References}

Aarseth, K.A., M. Sørensen y T. Storebakken 126, 75-91 (2006b) Effects of red yeast inclusions in diets for salmonids and extrusion temperature on pellet tensile strength: Weibull analysis, Anim. Feed Sci. Technol.

Behnke, K.c. (2001) Productivity parameters using pelleted vs. mash feeds. Dept. of Grain Science and Industry. - Kansas State University. Kansas - USA

Carrera, Z. (2011). Agroindustria Alimentaria. Efecto del uso de alimento balanceado peletizado,. Santa Cruz de Yojoa, Honduras.

Gallego Mejía, R. (s.f.). manual de construcciones y equipos para fábricas de alimentos concentrados.

García O.2015. Sistema de control de humedad en alimentos balanceados. Ismail O. (2008) Entender el proceso de peletizado para lograr mejores resultados. Giuliani S.A., Argetina. Industria Avícola

Keih, C. (2010). Alimentos de fabricación en planta de Alimentos

Keith C. Behnke, (2001).Processing Factors influencing pellet quality.

Keith C. Behnke, (2010) El arte del peletizado.

King, J. (1981 ). Introducción a la zootecnia. Zaragoza Spain: Editorial Acribia.

López, CAA. (1999) Efectos de la molienda conjunta y textura de la ración sobre la digestibilidad de nutrientes.

López. CC. (2005) Conceptualización sobre el Sistema Digestivo de los Pollos de Engorada y sus Implicaciones sobre la Productividad. Departamento de Producción Animal: Aves, FMVZ. Universidad Autónoma de México (UNAM).D.F. Mexico. 
Minorumiyasaka A. ( 2004) Objetivos Peletización. Technical Service COBB. Seminario COBB Produss. Casas G.O. (2015). Sistema de control de humedad en alimentos balanceados. 